\title{
Isolasi dan Identifikasi Cemaran Bakteri Escherichia Coli pada Telur Penyu Lekang (Lepidochelys olivacea) yang Gagal Menetas Menetas di Sarang Semi Alami Pantai Boom Banyuwangi
}

\author{
(ISOLATION AND IDENTIFICATION OF Escherichia coli CONTAMINATION IN \\ UNHATCHED OLIVE RIDLEY (Lepidochelys olivacea) SEA TURTLE EGGS IN SEMI- \\ NATURAL NEST, BOOM BEACH, BANYUWANGI)
}

\author{
Bhima Rochman Satya Haprabu'*, Hardany Primarizky², Prima Ayu Wibawati, \\ Wiyanto Haditanojo 4 \\ ${ }^{1}$ Bachelor of Veterinary Medicine, \\ ${ }^{2}$ Department of Clinic and Animal Hospital, \\ ${ }^{3}$ Department of Veterinary Public Health, \\ ${ }^{4}$ Banyuwangi Sea Turtle Foundation, \\ Faculty of Veterinary Medicine, Universitas Airlangga, \\ UNAIR C-Campus Mulyorejo, Surabaya, Jawa Timur, Indonesia, 60115 \\ Telp. (031)5993016, Fax. (031)5993015 \\ *Corresponding author: bhima.rochman.satya-2014@ fkh.unair.ac.id
}

\begin{abstract}
Abstrak
Tujuan dari penelitian ini adalah untuk mengidentifikasi bakteri Escherichia coli dalam telur yang gagal menetas dari penyu Lekang (Lepidoehelys olivacea) di sarang semi-alami, pantai Boom, Banyuwangi. Bakteri diisolasi dari 12 kuning telur penyu yang gagal menetas dan dari induk penyu yang berbeda. Pengambilan sampel dilakukan dengan teknik sampel random berstrata. Kontaminasi E. coli dideteksi dengan menggunakan uji pendugaan, uji konfirmasi, dan uji biokimia IMVIC, berdasarkan Standar Nasional Indonesia 01-2332.1-2015 tentang cara uji mikrobiologi-bagian 1: Penentuan coliform dan E. coli pada produk perikanan. Hasil penelitian ini menunjukkan bahwa sebanyak 3 sampel atau 25\% dari total sampel terkontaminasi $E$. coli, yaitu sampel B1, B3, dan C3. Berdasarkan Most Probability Number (MPN) Jumlah E. coli pada masing masing sampel adalah sampel B1 sejumlah 3 MPN/g, B3 sejumlah 7,2 MPN/g dan C3 sejumlah 9,2 MPN/g. E. coli bukan bakteri utama yang menyebabkan kegagalan penetasan telur penyu di sarang semi-alami, pantai Boom, Banyuwangi. Namun pada pengujian sampel ditemukan bakteri golongan koliform fekal pada sebagian besar sampel yaitu 8 sampel atau 66,67\%, koliform non fekal sebanyak 1 sampel atau 8,33\% dan non koliform sebanyak 3 sampel atau 25\% dari total 12 sampel. Sumber kontaminasi E. coli diduga berasal dari induk penyu, lingkungan sarang semi-alami, dan pekerja Banyuwangi Sea Turtle Foundation.
\end{abstract}

Kata kunci: Penyu Lekang, sarang semi-alami, Escherichia coli

\section{Abstract}

The aim of this research was to identify bacteria Escherichia coli in an unhatched egg of Olive ridley (Lepidoehelys olivacea) in a semi-natural nest, Boom beach, Banyuwangi. Bacteria were isolated from 12 sea turtle yolks that failed to hatch and from the different mature sea turtle. Sampling was done by stratified random sampling technique. E. coli contamination was detected using presumptive, confirmed, completed test and IMVIC biochemical test, According to Indonesian National Standard 01-2332.1-2015 on microbiological test methods-part 1: Determination of coliform and E. coli on fishery products. The results of this study showed that as many as 3 samples or $25 \%$ of the total samples were contaminated with E. coli. ie samples B1, B3, and C3. Based on Most Probability Number (MPN) the number of E. coli in each sample is B1 sample of 3 MPN/g, B3 of 7,2 MPN/g and C3 of 9,2 MPN/g. Escherichia.coli is not the main bacteria causing hatching failure in sea turtle eggs in a semi-natural nest, Boom beach, Banyuwangi. However, in the sample test found a fecal coliform group of bacteria in most samples that is 8 samples or 66,67\%, non fecal coliform of 1 sample or 8,33\% and non coliform of 3 samples or $25 \%$ from total 12 samples. The source of E. coli contamination may have came from the adult female, semi-natural environment, and the Banyuwangi Sea Turtle Foundation Staff.

Key words: olive ridley, semi-natural nest, Escherichia coli 


\section{PENDAHULUAN}

Salah satu jenis penyu yang terdapat di indonesia adalah penyu lekang (Lepidochelys olivacea). Semua jenis penyu saat ini telah masuk dalam daftar apendiks I (Pedoman Teknis Pengelolaan Konservasi Penyu, 2009). Pantai Boom di Kabupaten Banyuwangi merupakan salah satu tempat peneluran penyu lekang. Untuk meningkatkan populasi penyu, maka dibangunlah sarang penetasan semi-alami di pantai Boom. Namun pada sarang semi alami mengalami permasalahan dengan rendahnya tingkat penetasan telur. Diduga rendahnya tingkat penetasan telur diakibatkan oleh adanya cemaran bakteri.

Masa inkubasi telur penyu berada dalam pasir membutuhkan jangka waktu yang lama yaitu sekitar 51-55 hari, sehingga sangat rentan terhadap serangan mikroba (Clusella and Paladino, 2007; Anwar dkk., 2014). Selain itu struktur telur penyu yang lunak dan memiliki pori-pori berpotensi terinfeksi bakteri dan jamur karena bakteri dapat masuk melalui pori-pori dan mengkontaminasi telur penyu (Al-Bahry et al., 2011).

Menurut Lauckner, (1980) dalam Hidayat dkk., (2014), Escherichia coli merupakan salah satu bakteri dari golongan Enterobacteriaceae yang sering mengkontaminasi telur penyu, bakteri adalah kontaminan yang banyak terdapat pada lingkungan tanah ataupun pasir. Hasil penelitian Krisnaningsih dkk., (2005) menyatakan, E. coli merupakan penyebab kegagalan penetasan pada telur ayam. Selain dapat menyerang telur penyu, terdapat strain E. coli yang dapat menimbulkan penyakit serius pada manusia terutama pekerja yang ada di Banyuwangi Sea Turtle Foundation (BSTF), contohnya strain O157 H:7 yang bersifat zoonosis (Jawetz et al., 2013). Isolasi bakteri E. coli pada telur penyu Lekang gagal menetas masih belum banyak dilaporkan.

Berdasarkan latar belakang diatas perlu dilakukan penelitian mengenai Isolasi dan identifikasi cemaran bakteri Escherichia coli pada telur Penyu Lekang (Lepidochelys olivacea) yang gagal menetas di sarang semialami Pantai Boom, Banyuwangi. Penelitian ini sebagai dasar yang diharapkan dapat membantu dalam meningkatkan keberhasilan penetasan dalam upaya konservasi Penyu Lekang di Pantai Boom Banyuwangi.

\section{METODE PENELITIAN}

Penelitian ini dilakukan di Laboratorium Unit Pelaksana Teknis (UPT) Pengujian Mutu dan Pengembangan Produk Kelautan dan Perikanan (PMP2KP) Banyuwangi, Kabupaten Banyuwangi dan pengambilan sampel dari sarang semi alami milik BSTF yang terletak di pantai Boom Kabupaten Banyuwangi, Jawa Timur.

Pengujian melalui uji pendugaan koliform uji, pendugaan koliform fekal, uji penegasan, dan uji biokima. uji biokimia meliputi : Uji produksi Indol (I), Uji Voges Proskauer (VP), Uji Methyl Red (MR), dan Uji Citrate (C) (SNI, 2015). Isolasi dan Identifikasi bakteri E. coli dalam penelitian ini mengacu pada SNI 012332.1-2015 cara uji mikrobiologi. Sampel penelitian ini adalah 12 butir telur penyu lekang gagal menetas dan dilakukan pengenceran hingga 10-3 dengan larutan BPW dengan seri 3 tabung.

Peralatan yang digunakan dalam penelitian ini antara lain adalah cawan petri, tabung reaksi, rak tabung reaksi, tabung media, gelas ukur, pipet, tabung durham, jarum inokulasi (ose), spatula kaca, stomacher Barnstead International (BI), pembakar Bunsen, timbangan, inkubator merk dagang Binder tipe KB720, Waterbath (Techne) model FTE10AD, autoclave, gunting, pinset, kantong plastik klip, masker dan sarung tangan.

Escherichia coli Broth (ECB), hasil positif ditandai dengan terbentuk gas dan kekeruhan pada media. Hasil positif pada media ECB di lanjutkan uji penegasan menggunakan media Eosin Methylen Blue Agar (EMBA), hasil positif ditandai dengan tumbuhnya koloni berwarna hijau metalik.

Identifikasi karakter biokimia bakteri E. coli menurut kunci identifikasi Bacteria from Fish and Other Aquatic Animals (Buller, 2004). Hasil uji dilakukan pendugaan jumlah bakteri menggunakan Most Probability Number (MPN). 


\section{HASIL DAN PEMBAHASAN}

Jumlah keseluruhan yang teridentifikasi adanya bakteri E. coli dari 12 sampel cairan telur penyu yang gagal menetas berjumlah tiga sampel yaitu pada sampel B1, B3 dan C3. Hasil identifikasi bakteri E. coli didasarkan pada kunci identifikasi Bacteria from Fish and Other Aquatic Animals (Buller, 2004) dengan melihat sifat biokimianya pada uji biokimia IMVIC.

Tabel 1. Hasil uji lengkap E. coli

\begin{tabular}{|c|c|c|c|c|c|}
\hline & Sampel & Coliform (LTB) & $\begin{array}{l}\text { Coliform fecal } \\
\text { (ECB) }\end{array}$ & EMBA & Biokimia E. coli \\
\hline \multirow[t]{13}{*}{ Kontrol } & & + & + & $+*$ & $+{ }^{* * *}$ \\
\hline & $\mathrm{A} 1$ & + & - & $-*$ & $-* * *$ \\
\hline & $\mathrm{A} 2$ & + & + & $-*$ & $-* *$ \\
\hline & A3 & + & + & $-*$ & $-* *$ \\
\hline & B1 & + & + & $t^{*}$ & $t^{* *}$ \\
\hline & B2 & + & + & $-*$ & $-* *$ \\
\hline & B3 & + & + & $+^{*}$ & $t^{* * *}$ \\
\hline & $\mathrm{C} 1$ & + & + & $+^{*}$ & $-* *$ \\
\hline & $\mathrm{C} 2$ & + & + & $+^{*}$ & $-* *$ \\
\hline & $\mathrm{C} 3$ & + & + & $+^{*}$ & $+{ }^{* *}$ \\
\hline & D1 & - & - & $-*$ & $-* *$ \\
\hline & $\mathrm{D} 2$ & - & - & $-*$ & $-* *$ \\
\hline & D3 & - & - & $-*$ & $-* *$ \\
\hline
\end{tabular}

Keterangan: (+) terdapat aktifitas; $\left(+{ }^{*}\right)$ terbentuk koloni ciri khas E. coli; $\left(+^{* *}\right)$ positif terdapat E. coli; (-) tidak terdapat aktifitas; $\left(-^{*}\right)$ tidak terbentuk koloni ciri khas E. coli; $\left(-{ }^{* *}\right)$ negatif terdapat E. coli.

Angka MPN didapatkan dari hasil positif uji IMVIC untuk E. coli pada seri tabung pengenceran dan dicocokkan dengan tabel MPN seri 3 tabung. Sampel B1 menghasilkan angka 3 MPN/g, B3 menghasilkan angka 7,2 MPN/g dan C3 menghasilkan angka 9,2 MPN/g (lampiran 5). MPN akan menghasilkan angka $<3$ jika tidak terdapat hasil uji IMVIC positif untuk E. coli pada semua seri tabung pengenceran.

Didapatkannya cemaran E. coli pada sampel telur penyu gagal menetas sesuai dengan pernyataan Hidayat dkk (2014), yang menyatakan tentang bakteri yang sering mengkontaminasi telur penyu adalah E. coli. Terdapat 3 sampel telur penyu gagal gagal menetas yang tercemar oleh E. coli dari 12 sampel atau 25\% dari keseluruhan sampel. Sampel B1 menghasilkan angka $3 \mathrm{MPN} / \mathrm{g}, \mathrm{B} 3$ menghasilkan angka 7,2 MPN/g dan C3 menghasilkan angka 9,2 MPN/g, namun E. coli bukan merupakan penyebab utama kegagalan penetasan pada telur penyu lekang di tempat penetasan semi alami BSTF. Belum terdapat penelitian yang menyebutkan tentang standart cemaran bakteri pada telur penyu yang dapat menyebabkan kegagalan penetasan, namun Menurut Wicaksono (2017), jumlah mikroorganisme yang mencemari telur penyu sangat berpengaruh terhadap keberhasilan penetasan telur. Semakin tinggi jumlah cemaran bakteri akan menyebabkan penurunan tingkat keberhasilan penetasan pada telur penyu.

Hadirnya E. coli pada sampel telur penyu lekang yang gagal menetas, dapat dijadikan indikasi adanya bakteri patogen lain pada telur penyu maupun lingkungan (Elfidasari dkk., 2017). Penelitian ini juga berhasil membuktikan terdapat bakteri lainya pada telur penyu gagal menetas yaitu koliform fekal, koliform nonfekal, dan non-koliform melalui tahapan uji E. 
coli pada media Lauryl Tryptose Broth (LTB) dan Escherichia Coli Broth (ECB). Namun dalam penelitian ini masih belum dapat diidentifikasi hingga ketingkat spesies. Bakteri dari golongan koliform fekal adalah bakteri yang terdapat pada sebagian besar sampel, dapat terindikasi bakteri golongan ini sebagai penyebab utama kegagalan penetasan.

Cemaran bakteri pada telur penyu dapat berasal dari banyak sumber. Terdapat kemungkinan induk penyu lekang terinfeksi oleh bakteri E. coli. Keadaan ketika induk penyu mengalami infeksi sistemik pada oviduct oleh bakteri, hal ini dapat memungkinkan adanya bakteri didalam telur penyu (Rafferty et al., 2011). Pada penelitian Elfidasari dkk., (2017) menyatakan pencemaran oleh bakteri pada telur gagal menetas dapat terjadi saat sebelum cangkang terbentuk yang akan menginfeksi komponen telur, hal ini dapat terjadi ketika uterus dan ovarium dari induk telah terinfeksi bakteri.

Menurut Keene (2012), telur penyu juga dapat terkontaminasi E. coli dan bakteri koliform lainya melalui cairan kloaka saat pengeluaran telur oleh induk. Hasil Penelitian Elfidasari dkk., (2017) juga menyebutkan bahwa pada cairan kloaka penyu mengandung mikroba dalam jumlah yang tinggi. Tingginya jumlah mikroba dalam cairan kloaka disebabkan oleh kondisi pencernaan dari induk penyu, cairan kloaka berupa lendir yang ikut tersekresikan dan melapisi telur ketika pengeluaran telur oleh induk (Alkindi et al., 2006).

Penelitian Santoro et al., (2006), menyatakan E. coli termasuk bakteri yang sering menginfeksi penyu dan mengakibatkan abses kelenjar dan dinding peritoneum, bronkopneumonia, lesi pada integumen, rhinitis obstruktif, penyakit radang ulseratif, dan stomatitis ulceratif. Penelitian Oros et al., (2004) berhasil mengidentifikasi E. coli pada lesi gastrointestinal penyu Caretta caretta, Chelonia mydas dan Dermochelys coriacea.

Potensi lainnya adalah saat pemindahan telur dari sarang alami ke sarang semi-alami. Penggalian dan pengambilan telur di sarang semi alami dilakukan dengan tangan tanpa menggunakan sarung tangan steril (sterile glove), dapat terjadi perpindahan bakteri dari tangan petugas penggali ke telur penyu. Selain itu sanitasi peralatan pemindahan telur yang kurang baik juga berpotensi sebagai sumber pencemaran, contohnya ember plastik tempat penampung sementara saat telur akan di pindahkan.

Terdapatnya bakteri E. coli dalam sampel telur penyu gagal menetas dapat berasal dari lingkungan tempat penetasan, salah satunya pasir sebagai media inkubasi telur penyu. E. coli adalah bakteri yang banyak dijumpai pada lingkungan tanah, pasir ataupun perairan. Telur penyu akan berkontak dengan pasir dalam waktu yang lama sehingga rentan terhadap serangan bakteri yang ada di pasir (Anwar dkk., 2014). Kelembaban yang tinggi pada pada pasir sarang dapat meningkatkan pertumbuhan bakteri, karena kelembaban merupakan salah satu faktor lingkungan yang mendukung pertumbuhan bakteri (Sumarsih, 2003), sehingga perlu adanya penggantian pasir sarang semi alami secara rutin. Manajemen penggantian pasir pada sarang semi alami BSFT dilakukan dengan cara menukar pasir yang ada di lapisan atas dengan pasir yang ada di bawah sarang semi-alami yang dilakukan ketika musim bertelur penyu telah habis. Sistem tersebut di rasa kurang maksimal, selain itu pada sarang semi alami BSTF sering dilakukan penyiraman air pada sarang yang dimaksudkan menjaga kelembaban. Menurut Agrefishery (2010), penggantian pasir sarang media penetasan sarang semi-alami di Sukamade dilakukan 2 bulan sekali.

Terdapatnya bakteri E. coli pada sampel telur penyu gagal menetas dapat di hubungkan dengan keberadaan muara aliran sungai yang berasal dari perkampungan yang padat penduduk di dekat pantai Boom. Sampah rumah tangga banyak sekali ditemukan pada aliran sungai tersebut. Limbah rumah tangga merupakan sumber pencemaran biologis tertinggi, limbah yang berasal dari dapur, kamar mandi, cucian, industri rumah tangga serta kotoran manusia (Putra, 2004). Keberadaan E. coli dan koliform di dalam perairan dapat dijadikan indikator tercemarnya suatu perairan oleh kotoran manusia ataupun hewan mamalia (Rock and Rivera, 
2014). Bakteri yang berada dalam aliran sungai ini menuju ke laut, dan akan menuju pasir pantai melalui ombak. Keene (2012), menjelaskan bakteri yang terdapat di laut juga dapat mengkontaminasi pasir dan telur yang ada di sarang alami, diakibatkan oleh gelombang air laut yang membasahi pasir pantai.

\section{KESIMPULAN}

Terdapat Sampel telur penyu lekang (Lepidochelys olivacea) yang gagal menetas di sarang semi-alami di Pantai Boom, Banyuwangi, Jawa Timur yang tercemar $E$. coli yaitu pada tiga sampel atau $25 \%$ dari total sampel keseluruhan.

\section{UCAPAN TERIMA KASIH}

Peneliti mengucapkan terimakasih kepada Banyuwangi Sea Turtle Foundation (BSTF) yang telah memberikan izin untuk melakukan penelitian serta kepada petugas pantai Boom yang terkait dengan penelitian ini.

\section{DAFTAR PUSTAKA}

Agrefishery, M. 2010. Pengukuran Salinitas Menggunakan Alat Ukur Refraktometer. Penerbit PT Ichtiar Baru - Van Hoeve. Jakarta.

Al-Bahry, S.N., I. Mahmoud, Y. Melghit and K. Al-Amri. 2011. Analysis of Elemental Composition of the Eggshell Before and After Incubation in the Loggerhead Turtle Caretta caretta in Oman. Microscopy Microanalysis, 17: 1-9.

Alkindi, A.Y.A., I.Y. Mahmoud, M.J. Woller, J.L. Plude. 2006. Oviductal morphology in relation to hormonal levels in the snapping turtle, Chelydra serpentine. Tiss Cell, 38: 19-33.

Anwar, S., F.A. Febria, dan N. Nasir. 2014. Identifikasi Koleksi Jamur dari Cangkang dan Pasir Sarang Telur Penyu Lekang (Lepidochelys olivacea L.) di Penangkaran
Pariaman. Andalas. Jurnal Biologi Universitas Andalas, 3(1): 46-50.

Buller, N.B. 2004. Bacteria from Fish and Other Aquatic Animals. A practical Identification Manual. CABI publishing. Departmen of agiculture, Suth perth. Western Australia.

Clusella, T.S., and F.V. Paladino. 2007. Microenvironment of Olive Ridley Turtle Nest Deposited During an Aggregated Nesting Event. J Zool, 272: 367-376.

Direktorat Konservasi dan Taman Nasional Laut, Direktorat Jenderal Kelautan, Pesisir dan Pulau-Pulau Kecil, Departemen Kelautan dan Perikanan RI. 2009. Pedoman Teknis Pengelolaan Konservasi Penyu. Jakarta Pusat. Indonesia.

Elfidasari, D., G. Toufan, dan S. Irawan. 2017. Deteksi Cemaran Mikroorganisme pada Kawasan Konservasi Penyu di Pangumbahan Sukabumi. Al-Azhar Indonesia Seri Sains dan Teknologi, 4(1): 28.

Hidayat, O., F.A. Febria, dan N. Nasir, N. 2014. Isolasi dan Karakterisasi Bakteri pada Pasir Sarang dan Cangkang Telur Penyu Lekang (Lepidochelys olivaceae L.) yang Menetas dan Gagal Menetas. Padang. Jurnal Biologi Universitas Andalas, 3(2): 154-161.

Jawetz, E., J. Melnick, and E. Adelberg. 2013. Medical Microbiology. 26th edition. Mc Graw Hill. p233-234.

Kenee, E.L. 2012. Microorganisms from Sand, Cloacal Fluid, and Eggs of Lepidochelys olivacea and Standard Testing of Cloacal Fluid Antimicrobial Properties [Thesis]. Indiana. Opus: Research \& Creativity at IPFW.

Krisnaningsih, M. M. F., W. Asmara, dan M. H. Wibowo. 2005. Uji sensitivitas isolat Escherichia coli patogen pada ayam 
terhadap beberapa jenis antibiotik. $J$ Sain Vet, 1: 13-18.

Lauckner, G. 1880. Diseasis of Marine Mammals. Vol IV. Part 2. Biologische Anstalt Helgoland. Hamburg. p553-564.

Orós, J., S. Déniz, and P. Calabuig. 2004. Digestive pathology of sea turtles stranded in the Canary Islands between 1993 and 2001 Vet Rec, 155: 169-174.

Putra, Y. 2004. Pengolahan limbah rumah tangga (upaya pendekatan dalam arsitektur). e-USU Repository. Universitas Sumatera Utara.

Rafferty, A.R., P.S. Tomillio, J.R. Spotila, F.V. Paladino, and R.D. Reina. 2011. Embryonic death is linked to maternal identity in the leatherback turtle (Dermochelys coriacea). PLOS ONE, 6(6): e21038.
Santoro, M.G., M. Hernadez, Caballero and F. Garcia. 2006. Aerobic Bacterial Flora of Nesting Green Turtles (Chelonia mydas) from Tortuguero National Park, Costa Rica. J Zoo Wildlife Med, 37(4): 549-552.

Rock, C., and B. Rivera. 2014. Water Quality, E. coli and Your Health. The University of Arizona - College of Agriculture and Life Sciences - Cooperative Extension.

Sumarsih, S. 2003. Diktat kuliah: Mikrobiologi Dasar. Jurusan Ilmu Tanah. Fakultas Pertanian UPN "Veteran" Yogyakarta. Hal.81-82.

Wicaksono, M.A., F. Nurhasanah, D. Elfidasari, dan I. Sugoro. 2017. Cemaran Mikroba Pada Telur Penyu Sisik (Eretmochelys imbricata)) di Pulau Kelapa Dua, Taman Nasional Laut Kepulauan Seribu, DKI Jakarta. Jakarta. Jurnal Al-azhar Indonesia seri sains dan teknologi, 4(2). 